\title{
Demand for assistance in a human milk bank associated with socioeconomic and maternal-child health factors in Viçosa - Minas Gerais
}

\author{
Rafaela Mara Silva Fonseca' ${ }^{\mathbb{D}}$, Lilian Fernandes Arial Ayres' ${ }^{(D)}$, \\ Luana Cupertino Milagres $^{1}{ }^{(\mathbb{D})}$, Sylvia do Carmo Castro Franceschini' ${ }^{1}$, \\ Bruno David Henriques' ${ }^{(D)}$
}

'Universidade Federal de Viçosa, Viçosa, MG, Brasil

\begin{abstract}
The superiority of breast milk over milk of other species is already consolidated and there are numerous benefits in the practice of breastfeeding. The Human Milk Bank is a privileged place for the establishment of breastfeeding, as actions to encourage, support and promote breastfeeding are developed. This is a cross-sectional, retrospective study carried out at the only maternity hospital in the city. The sample consisted of mothers and babies assisted by a lactation support program from 2005 to 2016 and also mothers and babies monitored by the human milk bank. It was observed that the assistance of the milk bank was associated with the type of delivery performed (cesarean) (OR: 2.11 ; 95\% Cl: 1.03-4.33), having premature children (gestational age) (OR: 3, 48; 95\% Cl: 1.52-7.95), higher education (OR: 1.16; 95\% Cl: 1.03-1.32) and being younger (age) (OR: $0.94 ; 95 \% \mathrm{Cl} \%$ : 0.88-0.99) were the indicators that increased the mother's chance to seek care from the milk bank, regardless of parity and place of residence. The support, protection and promotion of breastfeeding that is carried out in this place, is configured as an important scenario favoring this practice, impacting on the health of the mother-child binomial in the present and in the future.
\end{abstract}

Keywords: Breastfeeding; Human milk bank; Lactation 


\section{INTRODUCTION}

The superiority of human milk to all other kind of animal milk is well documented and there are numerous benefits of breastfeeding (BRASIL, 2015). Exclusive breastfeeding promotes adequate growth and development, reduces infant morbidity and mortality, whether in high, middle, or low-income populations (GIUGLIANI, 2017).

No other single strategy can have a larger impact that breastfeeding has on reducing death of children under 5 years (BRASIL, 2015). The protection of breast milk against infant deaths is greater as the child is younger. Thus, mortality from infectious diseases is six times higher in not breastfed children under 2 months of age and decreases as the child grows, but it is still double in the second year of life (WHO, 2000).

Nutritional monitoring of children particularly during the first year of life is very important because this is an age group who shows marked vulnerability and childhood health conditions have an impact on adult life (CAVALCANTI et al, 2015; SILVA et al, 2008). Therefore, programs that promote actions of health and disease prevention through exclusive breastfeeding and adequate introduction of complementary foods are essential to public health and child quality of life (CALDAS et al, 2016).

A Human Milk Bank is a favored place for the initiation of breastfeeding, as it develops actions to encourage, support, and promote breastfeeding (BRASIL, 2008). The service, besides collecting and distributing human milk, has humanized care practices that support women and provide guidance on the importance of breastfeeding and the clinical management of nipple trauma in breastfeeding complications. The Human Milk Bank acts by assisting individually and/or collectively pregnant and postpartum women, training of health professionals for counseling and clinical management of breastfeeding, and carrying out campaigns and other activities related to the theme (BRASIL, 2008). 
In Brazil, evidence about factors associated with demand for assistance in a human milk bank is scarce. In this context, this is a pioneering study and aimed at assessing the relationship between socioeconomic and maternal and child health indicators of participants in a lactation support program with the demand for assistance at a Human Milk Bank (BLH).

\section{METHODOLOGY}

This is a cross-sectional retrospective study carried out at the maternity hospital in the city of Viçosa-MG, which mostly provides care through the Unified Health System (SUS), but also monitors private and health insurance patients. Viçosa is located in the Zona da Mata Region of Minas Gerais, at $227 \mathrm{~km}$ from the state capital Belo Horizonte. According to Census 2010, the municipality of Viçosa comprises an area of $299.4 \mathrm{Km}^{2}$ and 78.381 inhabitants, of which $93.2 \%$ live in urban areas (IBGE, 2011).

The sample consisted of mothers and babies assisted by PROLAC (Lactation Support Program) and mothers and babies monitored by the BLH, from 2005 to 2016. PROLAC is an Extension Program at the Federal University of Viçosa (UFV) that started in 2003 and has partnership with the Municipal Human Milk Bank. Among PROLAC's activities, assistance to mothers during hospitalization and care in postpartum stand out aiming at promoting breastfeeding, as well as offering nutritional care to nursing mothers and children in their first year of life.

The BLH is located at the São Sebastião Hospital, a high-risk maternity hospital and a reference for municipalities in the health region of Viçosa and others beyond. The unit was created in 2005, acts in the promotion and guidance on breastfeeding, and assists in difficulties in establishing breastfeeding. It is a reference for the Neonatal ICU, with human milk expressed and pasteurized, as well as the infant formula for newborns. It carries out campaigns to promote and support breastfeeding (AM) in the municipality and to attract milk donors. 
This study was carried out following the guidelines of resolution 466/2012 that regulates research with human beings (BRASIL, 2013). Before the milk collection started, the Project was analyzed and approved by the internal Commission of the São Sebastião Hospital and the Ethics Committee in Research with Human Beings of the Federal University of Viçosa (UFV) (committee opinion $n^{\circ}$ 2.190.943/2017).

Data on maternal health indicators (type of delivery, parity, gestational age, and marital status) were collected from the PROLAC medical records. The gestational age was classified as one of the following: premature (less than 37 weeks); term (more than 37 weeks); and post term (born after 42 weeks) (BRASIL, 1994).

The child indicators used were sex and birth weight. The weight classification was carried out according to the Ministry of Health (2011) as low weight ( $<2500 \mathrm{~g})$, adequate weight (above 2500g), and macrosomy (greater than 4000g) (BRASIL, 2011).

The socioeconomic and demographic indicators evaluated were income, education level, place of residence, insurance type, and number of prenatal appointments. Data on income were classified into three categories: less than 1 minimum wage, between 1 and 5 minimum wages, and more than 5 minimum wages, according to the organization of the PROLAC's medical records. Schooling was classified as groups of study years completed; the place of residence was classified as rural or urban, and the type of insurance as SUS, health insurance, or private covering. The performance of prenatal care was categorized by the minimum number of appointments recommended ( $<6$ and $\geq 6$ appointments) (BRASIL, 2012).

In the statistical analysis, the data were entered into Microsoft Office Excel 2013 database and analyzed using the program SPSS ${ }^{\circledR}$ version 21.0. Sample characteristics were described by absolute and relative frequency distribution, as well as median and interquartile range for variables without normal distribution. Normality of the data was assessed using the Kolmogorov-Smirnov test. 
Pearson's chi-square test, Fisher's exact test, and chi-square test for linear trend were used to explore the relationship of categorical indicators with the demand for assistance in the BLH. The Mann Whitney test was used to compare the medians of continuous variables in these two groups.

Multiple logistic regression was used to assess the association of socioeconomic, demographic, and maternal and child health indicators of participants in a lactation support program with the demand for assistance in a human milk bank. The odds ratio (OR) with a 95\% confidence interval (95\% CI) was used as a measure of effect. Bivariate analysis was performed using simple logistic regression models, with the demand for assistance in BLH as a dependent variable.

The predictive variables of demand for assistance in BLH with a $p$-value below 20\% ( $p<0.20)$ were entered in the multivariate model.

The location of prenatal care and the number of appointments were potential confounders of the relationship studied and, therefore, they are part of the multiple model. This occurs because, according to the literature, there is a relationship between these variables and better performance in breastfeeding (PELLEGRINELLI, 2015). The Hosmer \& Lemeshow test was used to verify the fit of the final model. The analyses considered a significance level of $0.05(\alpha=5 \%)$ for all tests performed.

\section{RESULTS}

In this study, the PROLAC sample consisted of 611 mother-child binomials, in which 65 (10.63\%) were served by the BLH in the same period. The median of age of mothers was 25 years (IIQ: 21 - 30) and the median of schooling was 10 years (IIQ: 8 - 11). Table 1 lists the characteristics of the study population, which had the highest prevalence of cesarean sections, income between 1 and 5 minimum wages, primiparity (first time mother), children born complete term, with normal birth weight, of adult mothers, living with their partner (married/cohabitating). Their schooling level was categorized as less than high school or completed high school, residence in the urban area, and prenatal care at SUS with at least 6 appointments.

Table 1 - Characteristics of the sample. Viçosa. Minas Gerais. 2018 
6 | Demand for assistance in a human milk bank associated with socioeconomic and maternal...

\begin{tabular}{|c|c|c|}
\hline $\begin{array}{c}\text { Variable } \\
\end{array}$ & $\mathbf{N}$ & $\%$ \\
\hline \multicolumn{3}{|l|}{ Type of Childbirth ( $n=605)$} \\
\hline Normal & 215 & 35.5 \\
\hline C-section & 390 & 64.5 \\
\hline \multicolumn{3}{|l|}{ Family Income $(n=584)$} \\
\hline$\leq 1 \mathrm{SM}$ & 223 & 38.2 \\
\hline$>1 \mathrm{SM}$ and $\leq 5 \mathrm{SM}$ & 319 & 54.6 \\
\hline$>5 \mathrm{SM}$ & 42 & 7.2 \\
\hline \multicolumn{3}{|l|}{ Parity $(n=608)$} \\
\hline Primiparous & 353 & 58.1 \\
\hline Multiparous & 255 & 41.9 \\
\hline \multicolumn{3}{|l|}{ Gestacional Age $(n=438)$} \\
\hline Preterm & 49 & 11.2 \\
\hline Term & 389 & 88.8 \\
\hline \multicolumn{3}{|l|}{ Place of Residence $(n=610)$} \\
\hline Urban & 565 & 92.6 \\
\hline Rural & 45 & 7.4 \\
\hline \multicolumn{3}{|l|}{ Birth weight $(n=606)$} \\
\hline Low birth weight & 41 & 6.8 \\
\hline Normal weight & 549 & 90.6 \\
\hline Macrosomy & 16 & 2.6 \\
\hline \multicolumn{3}{|l|}{$\operatorname{Sex}(n=609)$} \\
\hline Female & 298 & 48.9 \\
\hline Male & 311 & 51.1 \\
\hline \multicolumn{3}{|l|}{ Prenatal care $(n=593)$} \\
\hline SUS & 381 & 64.2 \\
\hline Health insurance & 118 & 19.9 \\
\hline Private & 94 & 15.9 \\
\hline \multicolumn{3}{|c|}{ Prenatal ( $n^{\circ}$ appointment) $(n=562)$} \\
\hline$\geq 6$ appointment & 469 & 83.5 \\
\hline$<6$ appointment & 93 & 16.5 \\
\hline \multicolumn{3}{|l|}{ Age $(n=601)$} \\
\hline Adolescent & 68 & 11.3 \\
\hline Adult & 533 & 88.7 \\
\hline \multicolumn{3}{|l|}{ Maternal Education $(n=591)$} \\
\hline$\leq$ High school & 485 & 82.1 \\
\hline Technical or higher & 106 & 17.9 \\
\hline \multicolumn{3}{|l|}{ Marital Status $(n=607)$} \\
\hline Single/separated/widowed & 176 & 29.0 \\
\hline Married/cohabitating union & 431 & 71.0 \\
\hline
\end{tabular}

The difference in sample size between variables is due to data loss because of the lack in medical records.

The comparison of socioeconomic, demographic, and maternal health indicators shows that mothers assisted by the BLH had higher number of prenatal 
appointments, had more education, mostly were primiparous with premature babies compared with unassisted mothers (Table 2).

Table 2 - Socioeconomic. demographic and maternal health indicators according to mothers assisted or not by BLH. Viçosa. Minas Gerais. 2018

\begin{tabular}{|c|c|c|c|}
\hline & \multicolumn{2}{|c|}{ BLH } & \multirow{2}{*}{ P Value } \\
\hline & Yes & No & \\
\hline \multicolumn{4}{|l|}{ Prenatal care $(n=593)$} \\
\hline SUS & $45(11.8)$ & $336(88.2)$ & \multirow[t]{3}{*}{0.673} \\
\hline Health insurance & $11(9.3)$ & $107(90.7)$ & \\
\hline Private & $9(9.6)$ & $85(90.4)$ & \\
\hline \multicolumn{4}{|c|}{ Prenatal ( $n^{\circ}$ appointments) $(n=562)$} \\
\hline$\geq 6$ appointments & $52(11.1)$ & $417(88.9)$ & \multirow[t]{2}{*}{0.478} \\
\hline$<6$ appointments & $8(8.6)$ & $85(91.4)$ & \\
\hline Age (years) $(n=601)^{\dagger}$ & $26(21.0-30.0)$ & $27(21.0-32.0)$ & 0.254 \\
\hline Education (years) $(n=591)^{\dagger}$ & $11(10.0-11.0)$ & $10(8-11)$ & 0.066 \\
\hline \multicolumn{4}{|l|}{ Place of Residence $(n=610)^{t \dagger}$} \\
\hline Urban & 65 (11.5) & $500(88.5)$ & \multirow[t]{2}{*}{0.213} \\
\hline Rural & $2(4.4)$ & $43(95.6)$ & \\
\hline \multicolumn{4}{|l|}{ Income $(n=584)$} \\
\hline$\leq 1 \mathrm{MW}$ & $19(8.5)$ & $204(91.5)$ & \multirow{3}{*}{0.241} \\
\hline$>1 \mathrm{MW}$ and $\leq 5 \mathrm{MW}$ & $42(13.2)$ & $277(86.8)$ & \\
\hline$>5 \mathrm{MW}$ & $5(1.9)$ & $37(88.1)$ & \\
\hline \multicolumn{4}{|l|}{ Type of Delivery $(n=605)$} \\
\hline Normal & $20(9.3)$ & $195(90.7)$ & \multirow[t]{2}{*}{0.302} \\
\hline C-section & $47(12.1)$ & $343(87.9)$ & \\
\hline \multicolumn{4}{|l|}{ Parity $(n=608)$} \\
\hline Primiparous & $37(10.5)$ & $316(89.5)$ & \multirow[t]{2}{*}{0.618} \\
\hline Multiparous & $30(11.8)$ & $225(88.2)$ & \\
\hline \multicolumn{4}{|l|}{ Marital Status $(\mathrm{n}=607)$} \\
\hline Single/separated/widowed & $12(6.8)$ & $164(93.2)$ & \multirow{2}{*}{$0.034^{*}$} \\
\hline Married/cohabitating union & $55(12.8)$ & $376(87.2)$ & \\
\hline \multicolumn{4}{|l|}{ Gestacional Age $(n=438)^{\dagger \dagger}$} \\
\hline Preterm & $3(6.1)$ & 46 (93.9) & \multirow[t]{2}{*}{0.602} \\
\hline Term & $38(9.8)$ & $351(90.2)$ & \\
\hline
\end{tabular}

*MW: salary. Pearson's Chi Square. † Nonparametric variables (median and interquartile range) assessed by the Mann Whitney test. $\dagger \dagger$ Fisher's exact test.

The simple logistic regression analysis indicated that the BLH assistance was associated with parity (primiparous), gestational age (preterm), higher education, and younger age (Table 3). After adjusting for confounding in the multiple logistic regression analysis, the indicators that increased the chance of a mother seeking 
care from the BLH were the C-section delivery (OR: 2.11; 95\% Cl: 1.03-4.33), having premature children (OR: 3.48; 95\% Cl: 1.52-7.95), higher education (OR: 1.16; 95\% Cl: 1.03-1.32), and younger age (OR: 0.94; 95\% Cl: 0.88-0.99) (Table 4).

Table 3 - Simple Logistic Regression for the association between socioeconomic. demographic. and maternal and child health indicators with the demand for assistance in a human milk bank. Viçosa. Minas Gerais. 2018

\begin{tabular}{|c|c|c|c|}
\hline Variable & OR & $\mathrm{Cl} 95 \%$ & P Value \\
\hline \multicolumn{4}{|l|}{ Type of Delivery } \\
\hline Normal & 1 & & \\
\hline Cesarean & 1.34 & $0.77-2.32$ & 0.194 \\
\hline \multicolumn{4}{|l|}{ Family income } \\
\hline$\leq 1 \mathrm{MW}$ & 1 & & \\
\hline$>1 \mathrm{MW}$ and $\leq 5 \mathrm{MW}$ & 1.63 & $0.92-2.88$ & 0.095 \\
\hline$>5 \mathrm{MW}$ & 1.45 & $0.51-4.13$ & 0.485 \\
\hline \multicolumn{4}{|l|}{ Parity } \\
\hline Multiparous & 1 & & \\
\hline Primiparous & 1.95 & $1.12-3.41$ & 0.019 \\
\hline \multicolumn{4}{|l|}{ Gestacional Age } \\
\hline Term & 1 & & \\
\hline Preterm & 2.68 & $1.30-5.54$ & 0.008 \\
\hline \multicolumn{4}{|l|}{ Place of Residence } \\
\hline Urban & 1 & & \\
\hline Rural & 0.36 & $0.08-1.51$ & 0.162 \\
\hline Maternal age (years) & 0.98 & $0.94-1.02$ & 0.249 \\
\hline \multicolumn{4}{|l|}{$\begin{array}{l}\text { Prenatal care ( } n^{\circ} \text { de } \\
\text { appointments) }\end{array}$} \\
\hline$\geq 6$ appointments & 1 & & \\
\hline$<6$ appointments & 0.99 & $0.89-1.10$ & 0.405 \\
\hline Education (years) & 1.08 & $0.99-1.17$ & 0.070 \\
\hline \multicolumn{4}{|l|}{ Marital status } \\
\hline Single/Separated/Widowed & 1 & & \\
\hline Married/cohabitating union & 1.10 & $0.62-1.95$ & 0.744 \\
\hline \multicolumn{4}{|l|}{ Prenatal } \\
\hline SUS & 1 & & \\
\hline Health insurance & 0.77 & $0.38-1.54$ & 0.455 \\
\hline Private & 0.79 & $0.37-1.68$ & 0.541 \\
\hline
\end{tabular}

Multivariate logistic regression. OR: Odds Ratio; 95\% Cl: 95\% confidence interval.

Table 4 - Multivariate logistic regression of the indicators associated with the demand for assistance in a human milk bank. Viçosa. Minas Gerais. 2018

\begin{tabular}{cccc}
\hline Variable & Adjusted OR & Cl 95\% & P \\
\hline
\end{tabular}




\begin{tabular}{lccc}
\hline Type of Delivery & 1 & & \\
Normal & 1 & $1.03-4.33$ & 0.042 \\
C-section & 2.11 & & \\
Gestacional Age & 1 & $1.52-7.95$ & 0.003 \\
Term & 3.48 & $1.03-1.32$ & 0.015 \\
Preterm & 1.16 & $0.88-0.99$ & 0.033 \\
Education (years) & 0.94 & & \\
Age (years) & & & \\
\hline
\end{tabular}

Multivariate logistic regression. OR: Odds Ratio; 95\% Cl: 95\% confidence interval. Model adjusted by place of follow-up and number of prenatal appointments.

\section{DISCUSSION}

The findings of this study showed that the demand for BLH was determined by the type of delivery (cesarean section), gestational age (premature), higher education, and mothers' age, regardless of parity and place of residence.

Higher maternal education was significantly associated with the demand for assistance at the BLH. This finding may be related to a better understanding of the importance and benefits of exclusive breastfeeding for the first six months (CAVALCANTI et al, 2015). In addition, information about the existence of a service such as BLH at the health system, which gives support to the breastfeeding process, may be more widespread among these women. Mothers (BRASIL, 2008).

The findings of this study corroborates prior researches in pointing out that the higher level of education contributes to the woman choosing exclusive breastfeeding for the first six months as recommended. This behavior may be related to access to information about the benefits of breastfeeding, emphasizing the increase and strengthening of the mother-child bond, less occurrence of diarrhea, otitis media, increased intelligence quotient (IQ), lower incidence of diseases in childhood and adulthood, among others (BRASIL, 2015; CALDAS et al, 2016; FALEIROS, 2006; PEREIRA, 2010).

The type of delivery influenced the demand for assistance in the BLH, being statistically higher for women who underwent cesarean section. This is because, in general, cesarean sections lead to a late initiation of breastfeeding due to prolactin 
levels, which are blocked with anesthesia and can delay milk production and breastfeeding (MANDARINO et al, 2009; ANSTEY, JEIVIT, 2011).

In addition, women feel more pain after the cesarean section, delaying the recovery and making the first breastfeeding difficult, while in normal delivery, the practice is facilitated (FALEIROS, 2006; BRASIL, 2001). In the C-section delivery, there is little active participation by women and less chance of skin-to-skin contact in the first minutes after birth, interfering with the early initiation of breastfeeding as recommended (PEREIRA, 2010; UNICEF, 2009).

The younger gestational age was related to a greater demand for assistance in the BLH. Several studies have demonstrated the difficulty that mothers of premature newborns face in maintaining breastfeeding, since most of them remain in the neonatal unit for a long time (GOMES et al, 2017; FREITAS et al, 2016). It is known, therefore, that mothers of premature babies have lower success rates in breastfeeding, which reinforces the need for strategies such as BLH, to support, promote, and strengthen breastfeeding (FREITAS, 2016; SBP, 2012; UNDERWOOD, 2013; TUDEHOPE, 2013; SILVA, SILVA, 2009).

The existence of human milk banks in hospitals that care for premature babies is an important care tool (EDWARDS, SPATZ, 2012). During the baby's stay in the Neonatal UTI, mothers are assisted by the BLH and are encouraged to maintain lactation with frequent milking. They are also encouraged to maintain skin-to-skin contact and non-nutritive sucking. Moreover, they receive guidance on how to manage the transition to nutritive sucking.

The family is guided to support the breastfeeding mother and the whole family nucleus must prepare for discharge from hospital (BRASL, 2011; FREITAS, 2016). Practice favors the maintenance of breastfeeding after hospital discharge and the support received may strengthen the bond with the mother of the premature baby. The interaction stimulates the continuous demand for assistance in the BLH even after discharge as these results indicate. Therefore, the assistance 
by the health professionals at the BLH during hospitalization is essential for maintaining breastfeeding in premature babies.

The study also showed that increasing mother's age decreased the demand for assistance by the BLH. This finding suggests older women have greater access to knowledge on the importance of breastfeeding and how to establish it. Studies show that older women tend to exclusively breastfeed their children up to six months, while the highest incidence of early weaning can be seen in younger women (DAMIÃO, 2008; CAVALCANTI et al, 2015). Knowledge about breastfeeding contributes not only to the woman's decision to breastfeed, but also to its duration (NASCIMENTO et al, 2013).

\section{CONCLUSION}

In conclusion, the demand for assistance in the BLH was by mothers who underwent C-section delivery, had premature children, higher education, and younger age. The Human Milk Bank is the appropriate place for pregnant women and mothers who need guidance during prenatal, postpartum, or any other stage of lactation. The support, protection, and promotion of breastfeeding that is carried out in at the HBM makes it an important place that favors this practice and impacts the health of the mother-child binomial in the present and in the future.

\section{REFERENCES}

BRASIL. Ministério da Saúde. Saúde da criança: aleitamento materno e alimentação complementar. Ministério da Saúde. Brasília. 2015; 2.ed.

GIUGLIANI ERJ, SANTOS, EKA. Amamentação exclusiva. In: Carvalho MR, Gomes CF. Amamentação: Bases científicas. $4^{a}$ edição. v.1,p.37. Rio de Janeiro, 2017.

WORLD HEALTH ORGANIZATION. Collaborative study team on the role of breastfeeding on the prevention of infant mortality: effect of breastfeeding on infant and child mortality due 
to infectious diseases in less developed countries: a pooled analysis. Lancet. 2000; 355 p. 451455.

CAVALCANTI SH, CAMINHA MFC, FIGUEIROA JN, SERVA VMSBD, CRUZ RSBC, LIRA PRC et.al. Fatores associados à prática do aleitamento materno exclusivo por pelo menos seis meses no estado de Pernambuco. Rev Bras Epidemio. 2015; 18(1): 208-19.

SILVA HGV et al. Diagnóstico do estado nutricional de escolares: comparação entre critério nacional e internacional. J. Pediatr.. 2008; 84 (6), p.550-555.

CALDAS DRC, OLIVEIRA ASSS, CUNHA EA, OLIVEIRA MR, LANDIM LASR, RAPOSO IAS. Aleitamento Materno e Estado Nutricional de Crianças Menores de um Ano de um Município do Nordeste do Brasil. Ensaios Cienc., Cienc. Biol. Agrar. Saúde. 2016; 20 (1), p.3-10.

BRASIL. Agência Nacional de Vigilância Sanitária (Anvisa). Banco de Leite Humano: funcionamento, prevenção e controle de riscos. Brasília: 2008; Anvisa.

IBGE. Instituto Brasileiro de Geografia e Estatística. Indicadores Sociais. Uma análise dos resultados do universo do Censo Demográfico 2010. Estudos \& Pesquisas: informações demográfica e socioeconômica; 2011.

BRASIL. Conselho Nacional de Saúde. Resolução n 466, de 12 de dezembro de 2012. Aprova normas regulamentadoras de pesquisas envolvendo seres humanos. Brasília: Diário Oficial da União, 2013.

BRASIL. Ministério da Saúde. Manual de Assistência ao Recém-nascido. Brasília, 1994; Ministério da Saúde.

BRASIL. Ministério da Saúde. Atenção à saúde do recém-nascido : guia para os profissionais de saúde. Brasília. 2011; Ministério da Saúde.

BRASIL. Ministério da Saúde. Atenção ao pré-natal de baixo risco. Departamento de Atenção Básica. Brasília. 2012; Ministério da Saúde.

PELLEGRINELLI ALR, PEREIRA SCL, RIBEIRO IP, SANTOS LC. Influence of pacifier use and bottle in exclusive breastfeeding among mothers treated at a Human Milk Bank. Rev. Nutr., Campinas. 2015; 28(6):631-639.

FALEIROS FTV, TREZZA EMC, CARANDINA L. Aleitamento materno: fatores de influência na sua decisão e duração. Rev. Nutr., Campinas. 2006; 19(5):623-630.

PEREIRA RSV, OLIVEIRA MIC, ANDRADE CLT, BRITO AS. Fatores associados ao aleitamento materno exclusivo: o papel do cuidado na atenção básica. Cad. Saúde Pública. 2010; 26(12):2343-2354. 
MANDARINO NR, CHEIN MB, MONTEIRO JFC, BRITO LM, LAMY ZC, NINA VJ, et al. Aspects related to choice of type of delivery: a comparative study of two maternity hospitals in Sao Luis, State of Maranhao, Brazil. Cad Saude Publica. 2009; 25(7): 1587-1596.

ANSTEY EH, JEIVIT C. Maternal obesity and breastfeeding a review of the evidence and implications for practice. Clinical Lactation. 2011; 2(3):11-6.

BRASIL. Ministério da Saúde. Parto, aborto e puerpério, assistência humanizada à mulher. Brasília: Secretaria de Políticas de Saúde, Ministério da Saúde; 2001.

PEREIRA CRVR, FONSECA VM, OLIVEIRA MIC, SOUZA IEO, MELLO RR. Avaliação de fatores que interferem na amamentação na primeira hora de vida. Rev Bras Epidemiol 2013; 16(2): 52534.

UNICEF. Fundo das Nações Unidas para a Infância/Organização Mundial de Saúde. Iniciativa Hospital Amigo da Criança: revista atualizada e ampliada para o cuidado integrado. Série A, Normas e Manuais Técnicos. Brasília; 2009.

GOMES ALM, BALAMINUT T, LOPEZ SB, PONTES KAES, SCOCHI CGS, CHRISTOFFEL MM. Aleitamento materno de prematuros em hospital amigo da criança: da alta hospitalar ao domicílio. Rev Rene. 2017; 18(6):810-7.

FREITAS BAC, LIMA LM, CARLOS CFLV, PRIORE SE, FRANCESCHINI SCC. Duração do aleitamento materno em prematuros acompanhados em serviço de referência secundário. Rev Paul Pediatr; 2016; 34 (2); p.189-196.

SBP. Sociedade Brasileira de Pediatria. In: Departamento Científico de Neonatologia, editor. Seguimento Ambulatorial do Prematuro de Risco. Rio de Janeiro. 2012; 1 ed.

UNDERWOOD MA. Human milk for the premature infant. Pediatr Clin North Am. 2013; 60. p.189-207.

TUDEHOPE DI. Human Milk. The Nutritional Needs of Preterm Infants. J Pediatr. 2013; 162, p. 17-25.

SILVA RV, SILVA IA. A vivência de mães de recém-nascidos prematuros no processo de lactação e amamentação. Esc Anna Nery Rev Enferm. 2009; 13 (1): 108-115.

EDWARDS TM, SPATZ DL. Making the case for using donor humanmilk in vulnerable infants. Adv Neonatal Care. 2012; 12:273.

DAMIÃO JJ. Influência da escolaridade e do trabalho maternos no aleitamento materno exclusivo. Rev Bras Epidemiol. 2008; 11(3): 442-52. 
NASCIMENTO VC, OLIVEIRA MIC, ALVES VH, SILVA KS. Associação entre as orientações pré-natais em aleitamento materno e a satisfação com o apoio para amamentar. Rev. Bras. Saúde Matern. Infant. 2013; 13 (2): 147-159.

\section{Authorship contributions}

\section{1 - Rafaela Mara Silva Fonseca}

Nutricionista, Mestre em Ciências da Saúde. https://orcid.org/0000-0001-5423-621X - rafaelamsfonseca@yahoo.com.br Contribuição: participou da concepção e delineamento deste trabalho e análise dos dados, foram realizadas as pesquisas bibliográficas, bem como a redação do manuscrito.

\section{2 - Lilian Fernandes Arial Ayres}

Professor Adjunto do Departamento de Enfermagem e Medicina da Universidade Federal de Viçosa, Doutora em enfermagem e biociências.

https://orcid.org/0000-0003-3809-2660 - lilian.ayres@ufv.br

Contribuição: auxiliou na coleta de dados, revisou e aprovou o manuscrito final, conforme apresentado.

\section{3 - Luana Cupertino Milagres}

Universidade Federal de Viçosa, Nutricionista, Doutora em Ciência da Nutrição. https://orcid.org/0000-0002-3186-7577 - luanamilagres@yahoo.com.br Contribuição: auxiliou na coleta de dados, revisou e aprovou o manuscrito final, conforme apresentado.

\section{4 - Sylvia do Carmo Castro Franceschini}

Professora Titular do Departamento de Nutrição e Saúde da Universidade Federal de Viçosa, Doutora em Nutrição.

https://orcid.org/0000-0001-7934-4858 - sylvia@ufv.br

Contribuição: supervisionou a análise dos dados, auxiliou na interpretação dos resultados e aprovou o manuscrito final, conforme apresentado.

\section{5 - Bruno David Henriques}

Professor Adjunto III do Departamento de Medicina e Enfermagem da a Universidade Federal de Viçosa, Doutor em Ciências da Saúde.

https://orcid.org/0000-0002-6844-6661 - brunoenfer@yahoo.com.br Contribuição: projetou o estudo, incluindo a coleta de dados, coordenou e supervisionou e aprovou o manuscrito final como submetido. 